\title{
GOLDEN EAGLE HUNTING TACTICS
}

\author{
by David R. M. Hatch, Oak Lake, Manitoba
}

Oak Lake, Manitoba, has been the wintering home of a few Golden Eagles (Aquila chrysaetos) during the past few years. They range widely in this vicinity and can frequently be seen in the least heavily populated areas. Farm homes are well scattered over the countryside, which is composed of marshes, open hay meadows and pasture fields, besides stands of trembling aspen bush. This bush habitat covers the sandhill ridges that run in a northwest-southeast direction across the prairie. The combination of woods, marshes, and open country seems to provide an ideal area for the Golden Eagle, and over the past three years I have had an excellent opportunity to observe their hunting techniques. The species, as a general rule, is wary and seldom comes near the farm homes, so opportunities for studying it are scarce. If an eagle knows humans are close, it soon moves to a safer location. Since during the duck and deer hunting seasons they are shot occasionally, they become very cautious when humans are in the vicinity. The only time I have been able to observe Golden Eagles hunting is when the "chase" is actually in progress, and at such time they seem to pay little or no attention to anything but their prey. Consequently the following observations are chance sightings made when I was in the right spot at the correct time.

On December 24, 1967, I was driving along a country road 10 miles south of the town of Oak Lake when I saw two Golden Eagles attacking a Red Fox (Vulpes fulva). The fox was about 200 yards from the road and running parallel to it across open country. The eagles, an adult and an immature, were working as a team. The immature eagle would dive-bomb the fox from behind, and just before it reached the fox the fox would turn and jump at the eagle. At this moment the adult eagle would hit the fox in the area of the shoulder blades just posterior to the base of the neck. The force of the blow would knock the fox down but it would get up and again continue running southward parallel to the road. Probably it was intent upon reaching cover onequarter of a mile distant. The eagles would immediately start another attack with the immature always coming in first and the adult reaching the target area only seconds behind. The immature came in at only about 25 yards off the ground, while the adult came in high and at about a 120 degree angle from the immature. The adult was probably about 150 yards high when it started its descent and came at the fox silently, whereas the immature made loud cries as it flew toward the fox. This resulted in drawing the fox's attention to the immature and therefore it never saw the adult eagle before it struck. This pattern was repeated four times while I watched, and on each occasion only the adult hit the fox. Each time the fox was knocked flat in the snow, and he was so slow getting on his feet after the third tremendous blow that he was unable to move more than 10 yards before the fourth attack, which proved terminal. On this occasion, the adult sank its talons into the shoulder region and held on. There was a fearful struggle in the snow with the immature eagle joining the battle and actually attacking the fox. What happened exactly is anyone's guess as all that could be seen was the confused mass of fox and eagles in a melee further blurred by the flutter of wings. The immediate result, however, was the death of the fox. After a few minutes I drove off leaving the eagles sitting on their well-earned prey. This was certainly an organized attack conducted with such efficiency that I have no doubt a similar tactic had been carried out 
several times prior to this occasion. As the attack was actually in progress when I arrived on the scene, I am unable to state how long it had been taking place, but I assume it had only just begun as the fox was still very fresh. Following the second attack that I witnessed however, the fox showed definite signs of being hurt and may have been lame as a result of the blow.

An earlier Golden Eagle-Red Fox incident that I witnessed was on February 6,1966 . On this occasion I was with Chuck Lacy, a biologist with Ducks Unlimited, and the observation was made near the village of Belleview, which is southwest of the lake called Oak Lake. It was just before sunset and we watched through $7 \times 50$ binoculars at a distance about onequarter of a mile. A fox was sitting on a small knoll and surrounding the fox were three Golden Eagles. They were spaced as though they were marking the corners of a triangle with the fox at the centre. They would sit quietly for a few minutes, then the fox would make a sudden dash across the open prairie. However, before the fox got more than 100 yards, two eagles would swoop in front of him causing the fox to turn around and run back to the knoll. The eagles remained right behind the fox as he returned to the knoll, then again took their triangular point positions. All four then sat quietly waiting for one another to move. The eagles appeared to tempt the fox into attempting to depart, as every once in a while one eagle would fly from its position and land right beside one of the two remaining eagles. The fox would again make an immediate break but always the results were the same: the two eagles chased it back to the knoll. This performance was repeated several times, but we could not wait for the ultimate outcome as darkness was fast approaching and drifting snow was making driving hazardous on the lonely country roads. It seems doubtful that anything came of this incident as the night was fast approaching and no attempt had yet been made to kill the fox. All three eagles chased the fox at one time or other, but one always remained on the knoll. Whether this was just a game for the eagles or an attempt to cause the fox to become fatigued so it could then be killed, one can only guess.

A third observation of a Golden Eagle pursuing its prey was made December 26, 1962. On this occasion the participants were an immature Golden Eagle and a White-tailed Jack Rabbit (Lepus townsendi). We were driving along a little-used country road that had a fence running along its eastern edge. We first saw the eagle at about 150 yards distance flying about 30 yards off the ground. Suddenly it dropped and seized a rabbit crouched in the snow. The eagle was able to lift the rabbit only two or three feet off the ground before its victim managed to struggle loose. The rabbit then darted across the open prairie in a zig-zag fashion moving constantly from the eagle's left to its right and back again. The eagle flew straight as an arrow, making no attempt to follow the rabbit's pattern, yet always keeping close to the rabbit. Once when the rabbit crossed just in front of the eagle, the eagle intercepted it and caught it in its talons, but again the rabbit squirmed free almost immediately. Within a few seconds, it had reached the fence paralleling the road on which we were stopped. The rabbit then hopped toward the car, being careful to remain against the fence. The eagle was unable to swoop down and capture it, being evidently unwilling to risk dashing into the wires. As the rabbit moved to within a few feet of the car, the eagle flew from post to post until it was only six posts from our car (a distance of approximately 100 feet). This was an extremely bold act on the part of both the rabbit and the eagle, and it must have been prompted out of sheer fear of the eagle in the rabbit's case and near starvation in the case of the eagle. Both the rabbit and the eagle sat quietly, each appearing to be waiting for the other to move. Suddenly the rabbit dashed into 
the open and across the snow, where it was quickly caught, for keeps this time. After sitting on the rabbit for a minute, the eagle commenced feasting on its prey. It is interesting to ncte that the rabbit managed to escape from the eagle's grip twice during the early stages of the chase. Why? One can only speculate, but three possibilities occur to me. It was a bitterly cold day with a strong wind and the wind might have affected the eagle's hold on the rabbit by upsetting its balance. The eagle was an immature and thus probably not exper- ienced in capturing rabbits. The rabbit appeared big and healthy and may have been nearly too heavy for the young eagle.

These observations of predation by eagles are supported by accounts in A. C. Bent's Life Histories of North American Birds of Prey; Golden Eagles were recorded taking a fourpoint White-tailed Deer, Pronghorn, and foxes.

I would like to thank Dr. R. F. B. King, Dean of the Faculty of Arts at Brandon University, for his assistance with this article.

\section{COLLECTIVE PARENTAL CARE BY TREE SWALLOWS}

\section{by Wayne Miller, 2 Almond Crescent, Brandon, Manitoba}

On July 3, 1966 Mr. John Lane noted two male Tree Swallows (Iridoprocne bicolor) feeding nestling swallows in a nest box several miles south of Chater, Manitoba. Mr. Lane took photographs in order to record this unusual incident of two males attending the same nest. A year later I made similar and related observations which form the basis for this note.

On July 16, 1967, at nest box 902 (Brandon Junior Birders' Nest Project) located to the northwest of Oak Lake, seven adult swallows defended the three-day-old young upon my close approach to the site. Three days later (July 19) when an Eastern Kingbird (Tyrannus tyrannus) perched near the box, a female swallow vigorously pursued it, urged on by two male swallows. Both of the latter then took flight and escorted the female back to the box, at which time a second female entered the nest. The intruding pair of swallows appeared strongly possessive and finally the "proper" male gave chase, apparently confused as to which was his mate, for a third female had appeared on the scene and had entered the box.

At ancther site south of this location, also near Oak Lake and on the same date, nine adult swallows (six males and three females) were found perched at nest box 1159. These birds were all aiding the six fully-fledged young to fly, and were coaxing the remaining three young from the box. I took one bird from the nest and released it, whereupon it took flight for the first time, followed and assisted by four adult male swallows.

I suspect, judging by the above observations, that for various reasons, including a scarcity of nesting cavities, many pairs of swallows are unable to nest, or have had an unsuccessful nesting. These birds, which retain the parental instinct, encroach on nesting pairs and aid with the parental duties, including feeding of the young and defense of the nest.

EDITOR'S NOTE: Volume two of "Studies in the life history of the Song Sparrow" (Dover edition, 1964), by Mrs. Margaret M. Nice, contains a discussion of this subject under the title: "Helpers at the nest." A variety of species have been observed responding to the begging behaviour of young of other species by feeding them. "Unmated helpers" of the same kind are also frequent and in some species one or more helpers occur fairly regularly. Extra birds of either sex have been previously recorded, for example, feeding at nests of the Tree Swallow, European Barn Swallow (Hirundo rustica), and Violet-green Swallow (Tachycineta thalassina). It would be valuable and instructive to have further observations of this interesting behaviour in the Tree Swallow, particularly if it were possible to follow the details of its development in a given situation. 